\title{
DO SPIN-OFFS REALLY CREATE VALUE? THE EUROPEAN CASE
}

By

\section{Chris Veld $^{*}$ and Yulia V. Veld-Merkoulova**}

December 16, 2002

\author{
JEL-codes: G32 and G34
}

\footnotetext{
* Corresponding author. Chris Veld is a Professor of Finance at the Department of Finance and CentER and a Professor of Personal Financial Planning at the Department of Fiscal Economics at Tilburg University. Postal address: Tilburg University, Room B 609, P.O. Box 90153, 5000 LE Tilburg, the Netherlands. Tel: +3113-4663257; fax: +3113-4662875; e-mail: C.H.Veld@kub.nl. Part of the research for this project was completed when Chris Veld was visiting York University in Toronto. We thank Matthew Billett, Abe de Jong, Randall Morck, Bas Werker, two anonymous referees, participants at the European Financial Management Conference in Lugano (June 2001), at the Financial Management Conference in Toronto (October 2001), and at seminars at the Erasmus University in Rotterdam, Tilburg University, the Tinbergen Institute, the University of Antwerp (UFSIA), the University of Toronto, and York University for helpful comments and suggestions. In addition we thank I/B/E/S International, Inc., for providing us earnings forecast data as part of an academic program to encourage earnings expectations research. Special thanks go to Joost van Zadelhoff (Nyenrode University and Rabobank Structured Finance) for his information on the taxation of spin-offs in individual European countries. The excellent research assistance of Ellen Hennekens and Niall Quann and editing assistance of Nicole Rijnen is gratefully acknowledged. This project has been supported financially by the Foundation "Vereniging Trustfonds Erasmus Universiteit Rotterdam" and the Moret Foundation ("Stichting Moret Fonds") in the Netherlands. The usual disclaimer applies.

Yulia Veld-Merkoulova is a Ph.D.-student at the Faculty of Economics of the Erasmus University Rotterdam and at the Tinbergen Institute. Part of the research for this project was completed when Yulia Veld-Merkoulova was visiting the University of Toronto.
} 


\title{
DO SPIN-OFFS REALLY CREATE VALUE? THE EUROPEAN CASE
}

\begin{abstract}
:
We study wealth effects for a sample of 156 spin-offs from 15 different European countries that were announced between January 1987 and September 2000. The cumulative average abnormal return over the three-day event window is $2.62 \%$. This number increases to $2.66 \%$ for the subsequently completed spin-offs. The cumulative average abnormal return is $3.57 \%$ for completed spin-offs by companies that increase their industrial focus and only $0.76 \%$ for non-focus increasing companies. The difference between these two sub-samples is significantly different from zero. These results are in line with previous studies for the United States. The long-run returns in excess of matching firms are mostly insignificant for parents, subsidiaries and pro-forma combined firms. This result suggests that, unlike U.S. spin-offs, European spin-offs are not associated with long-run superior performance.
\end{abstract}




\section{Introduction}

There is a broad consensus in both the academic and the popular literature that spin-offs create value. This consensus is based on the fact that a number of U.S. studies have shown that the announcement of a spin-off is associated with positive abnormal returns. Moreover, spin-offs also seem to exhibit long-run excess returns over periods from 6 months to 3 years after the spin-off is completed. In the last decade, the popularity of spin-offs has also spread to Europe. The positive wealth effects that were found for U.S. spin-offs may have caused this. The availability of a large sample of European spin-offs allows us to test the hypothesis whether spin-offs really create value.

A spin-off is a pro-rata distribution of the shares of a firm's subsidiary to the shareholders of the company. No cash transaction takes place. After the spin-off, the shareholders of the parent company hold shares in both the parent company and the subsidiary. Announcements of spin-offs by U.S. firms are associated with strongly significant abnormal returns that range from $1.32 \%$ to $5.56 \%$. Spin-offs of companies that increase their industrial focus by divesting a division in a different branch than the parent company are associated with higher abnormal returns than spin-offs of companies that do not increase their industrial focus (see e.g. Daley et al. (1997), and Desai and Jain (1999)). In addition, Krishnaswami and Subramaniam (1999) also find that firms with higher levels of information asymmetry exhibit higher abnormal returns in the announcement period. These results show that the market efficiently responds to the spinoff announcements by incorporating expected future benefits into the current stock price. A number of U.S. studies also find long-run superior performance of spun-off firms and their parents. Cusatis et al. (1993), Desai and Jain (1999), and McConnell et al. (2001) find that parents and subsidiaries, involved in a spin-off, outperform matching firms. Contrary to the results for the announcement period, the finding for the long-run excess returns is remarkable. According to the efficient market hypothesis, the positive effects of the spin-off should be incorporated in the announcement date returns. An interesting question is then whether spin-offs are really associated with positive long-run excess

\footnotetext{
${ }^{1}$ See e.g. Rosenfeld (1984), Copeland et al. (1987), Slovin et al. (1995), Johnson et al. (1996), Daley et al. (1997), Desai and Jain (1999), Krishnaswami and Subramaniam (1999), Mulherin and Boone (2000), and Maxwell and Rao (2003).
} 
returns or whether the U.S. results were a consequence of chance. Fama (1998) argues that studies finding significant long-run returns receive more attention in the academic and the popular literature because they are more interesting. For this reason Fama (1998), and Lyon et al. (1999) argue that it is useful to study such anomalies out-of-sample. In the case of spin-offs it makes sense to study spin-offs outside the United States. This gives us out-of-sample results on the long-run performance of companies involved in spin-offs.

In this paper we study European spin-offs ${ }^{2}$. Spin-offs have only become popular in Europe during the second half of the 1990s. In the period from 1987 to 1994, only 62 spin-offs took place. From 1995 onwards the volume of spin-offs rapidly increased. The period from January 1995 to September 2000 witnessed no less than 170 European spinoffs. Different results between the United States and Europe can a priori be expected due to corporate governance differences. Differences in corporate governance between countries can be measured by means of the index of La Porta et al. (1998). According to this index, shareholders of companies in continental Europe are less protected than shareholders in Anglo-Saxon countries.

The most important results from this study can be summarized as follows. In total, 156 spin-offs that were announced by European companies over the period from January 1987 to September 2000 are analyzed. The cumulative average abnormal return is $2.62 \%$ over the three-day event window. This number increases to $2.66 \%$ for the subsequently completed spin-offs. The cumulative average abnormal return is $3.57 \%$ for completed spin-offs by companies that increase their industrial focus and only $0.76 \%$ for non-focus increasing companies. The difference between these two sub-samples is significantly different from zero. This result is in line with previous studies for the United States. The divestiture of relatively large subsidiaries is also associated with larger abnormal returns. Contrary to Krishnaswami and Subramaniam (1999), we do not find any relation between the level of information asymmetry and the size of the abnormal return. However,

\footnotetext{
${ }^{2}$ Other empirical research on announcements of non-US spin-offs was carried out by Janssens de Vroom and Van Frederikslust (2000), and Murray (2000). Janssens de Vroom and Van Frederikslust (2000) find positive abnormal returns for their "English Legal Origin sample" of 176 observations (that mostly includes the United States and the United Kingdom) and insignificant abnormal returns for their "Other Legal Origin sample" of 34 observations. Murray (2000) finds positive abnormal returns for UK companies. Both studies only look at announcement date returns and not at long-run excess returns.
} 
introducing information asymmetry in the regression weakens the industrial focus effect. Therefore, the evidence on the industrial focus effect is not conclusive. The short-run results are not different between countries with different corporate governance systems.

Long-run excess returns, defined as the difference between the company return and the return on a matching firm, are mostly insignificant. The long-run excess returns in our study are higher for countries with lower levels of shareholder protection. Therefore, it cannot be concluded that the difference between our results and previously published results for the United States can be attributed to differences in corporate governance systems. If that were the case, the long-run excess returns in the underlying study would have been higher for countries with higher levels of shareholder protection. The results in this paper support the efficient market hypothesis. We conclude that spin-offs really create value, as they are associated with positive abnormal returns on the announcement date. However, unlike U.S. studies, we do not find evidence for positive long-run excess returns.

The rest of this paper is organized as follows. In Section 2 we discuss the factors that can explain the wealth effects from spin-offs. The data description and the methodology are included in Section 3. The empirical results are included in Section 4. The paper is concluded in Section 5 with a summary and some conclusions.

\section{Factors that can explain the wealth effects from spin-offs}

\subsection{Improvement of industrial focus}

The motive that is most frequently mentioned in literature for conducting a spin-off is the intention of the firm to concentrate on its core business. Daley et al. (1997), Krishnaswami and Subramaniam (1999) and Desai and Jain (1999) find that the abnormal returns for the focus increasing spin-offs are larger than for the non-focus increasing spin-offs. Focus-increasing spin-offs are generally defined as spin-offs in which the

parent company has a different two-digit Standard Industry Classification (SIC) code than the subsidiary. Desai and Jain (1999) also study the long-run performance of spinoffs after the announcement date. This leads to the interesting result that the superior 
performance of the focus-increasing spin-offs persists in the post-spin-off period. We test the hypothesis that spin-offs of firms that increase their industrial focus will be associated with higher abnormal returns than spin-offs of firms that do not increase their industrial focus.

\subsection{Information asymmetry}

Krishnaswami and Subramaniam (1999) argue that firms may engage in a spin-off because there is information asymmetry between the management of the firm and the external capital market. This information asymmetry may result in undervaluation of the firm. After the spin-off information asymmetry, and hence undervaluation, are likely to decrease. Krishnaswami and Subramaniam (1999) find that firms with higher levels of information asymmetry exhibit higher abnormal returns adjusted for the probability of a spin-off upon the announcements of spin-offs.

Habib et al. (1997) also present an information-based explanation for spin-offs. They derive a model in which a firm can increase its value by spinning off a subsidiary. The spin-off will lead to an increase of the number of securities that is traded on the market. This makes the price system more informative and, hence, leads to a decrease of information asymmetry. This decrease of information asymmetry will lead to an increase of the total value of the firm and it's spun off subsidiaries.

The Krishnaswami and Subramaniam (1999) paper suggests the testable hypothesis that spin-offs of firms with large information asymmetries will be associated with higher abnormal returns than spin-offs of firms with low information asymmetries. The Habib et al. (1997) paper leads to the hypothesis that firms, which show a decrease in information asymmetry after the spin-off, are associated with positive long-run excess returns.

\subsection{Corporate governance}

It is often argued that managers in Anglo-Saxon countries are more focussed on shareholder value creation, and that managers in continental European countries are more likely to take the interests of all the firm's stakeholders into account (see e.g. Moerland 
(1995)). According to La Porta et al. (2000), their index of "shareholder rights", which stems from La Porta et al. (1998), is a suitable measure for corporate governance differences between countries. This index ranges from zero to seven. A high value of the index means that shareholders are better protected against the adverse behavior of managers. We analyze whether spin-offs in countries with lower shareholder protection are associated with lower abnormal returns than spin-offs in countries with higher shareholder protection.

\subsection{Geographical focus}

Companies that spin off a foreign division can increase their geographical focus. Based on the literature on the relationship between geographical diversification and firm value, it is possible to both derive hypotheses that predict a positive relationship between spinoff announcements and an increase in geographical focus and hypotheses that predict a negative relationship ${ }^{3}$. The first reason for an increase in geographical focus to lead to a reduction in firm value is that it is possible that the spin-off of a foreign division may lead to reduced economies of scale in production. The second reason is that the spin-off may signal that the firm might previously have made a poor decision expanding to the foreign market. The third reason is that the firm may be at a relative disadvantage to competitors who operate internationally. Other theories state that an increase in geographical focus may lead to an increase in firm value. First, the reduced complexity of the firm may lead to lower monitoring and coordinating costs. Second, the managers might have chosen to globally diversify in order to decrease their own risks even if it results in lower shareholder value. Third, the possibility of cross-subsidization of less efficient divisions is reduced.

Given the arguments presented above, an increase in geographical focus may either be associated with higher or with lower abnormal returns than spin-offs of firms that do not increase their geographical focus. The outcome depends on the strength of the arguments in favor of a decrease in geographical focus versus the arguments in favor of an increase

\footnotetext{
${ }^{3}$ See e.g. Bodnar et al. (2000) and Denis et al. (2002) for an overview of these competing theories.
} 
of geographical focus. The geographical focus dummy corresponding to an increase in geographical focus is designed to measure the effect on shareholder value in our sample.

\subsection{Other variables}

In the U.S. some spin-offs are taxable ${ }^{4}$. Empirical research by Copeland et al. (1987), and Krishnaswami and Subramaniam (1999) shows that taxable spin-offs are associated with lower positive abnormal returns than non-taxable spin-offs. Spin-offs in European countries generally do not create tax problems, because it is possible to defer tax payments (see the appendix for details). Exceptions apply to Germany, France and the Netherlands (before 1998). In Germany, spin-offs can be arranged in a tax-neutral way. However, if more than $20 \%$ of the shareholders transfer their shares within 5 years after the spin-off, the spin-off will still be taxed (Zaman (1998)). In France, the problem is that it is not possible for the company to ask for approval from the tax authorities before the transaction is carried out. In both Germany and France, it is not known at the announcement date whether the spin-off will be taxed. The decision on the taxation in France will only be taken after the spin-off date. In Germany it will depend on the transfer of shares in the period after the spin-off. For this reason we do not include a variable on taxation in our analysis.

Schipper and Smith (1983), and Krishnaswami and Subramaniam (1999) have studied whether regulatory motives play a role for American companies to engage in a spin-off. Both studies show that the abnormal returns are not affected by the regulatory status of the spin-off. In the appendix we discuss the regulatory consequences of European spinoffs. From this appendix it can be concluded that regulation does not cause an obstacle for spin-offs to be carried out in European countries. An analysis of the literature on the regulation of spin-offs in Europe has also not led to a motive that makes spin-offs particularly attractive for regulatory purposes.

\footnotetext{
${ }^{4}$ See Schipper and Smith (1983), Copeland et al. (1987, page 136), and Krishnaswami and Subramaniam (1999) for a discussion on the tax consequences of U.S. spin-offs.
} 
Another potential explanation for the positive stock market reaction to spin-off announcements is the possibility to transfer wealth from bondholders to shareholders 5 . The measurement of this effect requires the use of bond data. However, since most European companies use non-tradable bank debt instead of bonds, we cannot measure this effect for the firms in our sample.

A number of studies find that the wealth effects are larger when the portion of assets that is divested is larger (see, e.g., Hite and Owers (1983), Miles and Rosenfeld (1983), and Krishnaswami and Subramaniam (1999)). In our study we control for this by using the market value of equity of the divested subsidiary relative to the sum of the equity capitalizations of the parent and the subsidiary. This is computed on the day of the completion of the spin-off.

\section{Data description and methodology}

\subsection{Data description}

We analyze a sample of European spin-offs. A European spin-off is defined as a spin-off in which a European parent spins off a subsidiary. This subsidiary can be either from the same or from a different country. All European countries are taken into account with the exception of the Eastern European, formerly Socialist, countries.

The sample covers the period from January 1987 to September 2000. The announcement dates are obtained from the Securities Data Company (SDC) Mergers and Acquisitions Database. Data on stock prices market values of equity and market indices are derived from Datastream. Primary SIC codes are from the Compustat (where available) and SDC databases. The original sample consisted of 230 European spin-offs. Table 1 reports the annual distribution of the announcements to spin-off a part of the company.

\footnotetext{
${ }^{5}$ Hite and Owers (1983), Schipper and Smith (1983), and Dittmar (2003) find that the announcement period bond returns are not significantly different from zero. Schipper and Smith (1983), and Dittmar (2003) find that only a small number of companies decline in bond ratings after the spin-off. On the other hand, a recent study by Maxwell and Rao (2003), on a large sample of spin-offs, does find evidence that bondholders on average suffer a significantly negative abnormal return in the month of the spin-off announcement. Another study that finds such a wealth transfer is Parrino (1997). In a case study of the Marriott spin-off he shows that the restructuring not only reduced the collateral on Marriott's existing debt, but also reduced the bondholder claims on cash flows from the business.
} 
[Please insert Table 1 here]

The row with the total number of observations shows that with $44 \%$ the United Kingdom is heavily represented in the total sample (102 out of 230 observations). Other countries that are relatively well represented include Sweden with 30 observations (13\%), Germany with 18 observations (8\%), Norway with 18 observations (8\%) and Italy with 14 observations $(6 \%)$. The remaining 10 countries take up $21 \%$ of the sample (48 observations). The last column of Table 1 shows that the distribution in time is also disproportionate. Most announcements, 168 (73\%), were made in the period from January 1995 to September 2000. The period from 1987 up to and including 1994 only counted for $62(27 \%)$ observations.

A number of spin-offs had to be eliminated from the original sample. The first reason is that a parent company sometimes announced spin-offs of two or more subsidiaries simultaneously. We checked for these double records and eliminated 16 double counts. We also eliminated announcements where one subsidiary was spun off by multiple parents. The only case where this applied was with the English utility National Grid. This led to the elimination of 7 announcements. The third reason is that for a large number of companies no stock prices were available in Datastream and/or the announcement was contaminated with other important financial news on the company. This led to the elimination of 51 observations. This final sample consists of 156 observations. The final sample still shows a large representation of the United Kingdom with 70 observations (45\%), Sweden with 24 observations (15\%), Germany with 14 observations (9\%) and Italy with 11 observations (7\%). On the last row of Table 1 it can be concluded that out of these 156 spin-off announcements, 108 were completed at the moment this research was finalized (April 2002), 31 were still pending and 17 were withdrawn.

\subsection{Proxies}

The variables that are used in the analysis are related to the hypotheses described in section 2 .

Industrial focus. An improvement in industrial focus is measured using a dummy variable. This variable is 1 if the two-digit SIC code of the subsidiary is different from 
the two-digit SIC code of the parent (spin-off of an unrelated division) and 0 if the twodigit SIC codes are the same ${ }^{6}$.

Information asymmetry. The information variable that is used, the normalized standard deviation of forecasts, is derived from the Institute of Brokerage for Investment Services (IBES). This variable is measured as the standard deviation of all earnings forecasts made in the last month of the fiscal year preceding the spin-off announcement year. The idea behind this variable is that disagreement between analysts is an indication of information asymmetry. We normalize the standard deviation by dividing it by the stock price of the firm in the middle of the month in which the standard deviation of forecasts is measured. We have also made calculations for a second variable, i.e. the earnings forecast error measured before the announcement of the spin-off, from now on to be referred to as the forecast error ${ }^{7}$. Both variables are positively and significantly (at the $1 \%$-level) correlated. They also generally give the same results. For this reason we only report results for the normalized standard deviation of forecasts ${ }^{8}$.

Shareholder rights. Shareholder rights are measured using the index put forward by La Porta et al. (1998). The index ranges from zero (very low shareholder protection) to seven (very high shareholder protection). Not surprisingly, the value of the index is lower for countries in continental Europe than for Anglo-Saxon countries 9 .

Geographical focus. Like industrial focus, an increase in geographical focus is measured using a dummy variable. This variable is 1 if a foreign division is spun off and 0 if a domestic division is spun off.

Relative size. Relative size is measured as the market value of equity of the divested subsidiary relative to the sum of the equity capitalizations of the parent and the subsidiary. This is computed on the day of the completion of the spin-off (see also

\footnotetext{
${ }^{6}$ Ideally we would also like to use data on the number of segments and on the segment sales. However, the data for these variables are not available in Compustat for European companies. This is probably caused by the fact that in most European countries there is no legal obligation to report data on segment sales.

${ }^{7}$ The average earnings forecast in the last month of the year preceding the spin-off announcement is defined as the predicted earnings. The forecast error is defined as the ratio of the absolute difference between the predicted earnings and the actual earnings per share to the stock price in the middle of the forecast month. Firms with more information asymmetry are expected to have higher forecast errors.

${ }^{8}$ Results for the forecast error are, on request, available from the authors.

${ }^{9}$ The index has the following values for the countries in our study: United Kingdom (5), Germany (1), France (3), Italy (1), Sweden (3), Norway (4), Denmark (2), Finland (3), the Netherlands (2), Belgium (0), Switzerland (2), Spain (4), Austria (2), Ireland (4) and Greece (2).
} 
Krishnaswami and Subramaniam (1999)). The mean market value of the parents after the spin-off is 5,642 million US dollars with a median of 921 million US dollars. This is much higher than the market value of the parents in studies on US spin-offs. For example, Desai and Jain (1999) report an average post spin-off market value of 1,123 million US dollars with a median of 268 million US dollars. Krishnaswami and Subramaniam (1999) report statistics that are close to the ones reported by Desai and Jain (1999). The mean relative size in our sample is $33.51 \%$ with a median of $29.62 \%$. A comparison with the US studies shows that the relative size of the subsidiaries is also larger than in the United States. For example, Desai and Jain (1999) find a mean relative size of $21.5 \%$ and a median of $13.8 \%$.

\subsection{Methodology}

\section{Event-study methodology}

The announcement effects of the spin-offs are measured using an event study methodology as described in, e.g., Mikkelson and Partch (1986) and Hite and Owers (1983). The market index chosen is the Datastream total return index for the individual European countries ${ }^{10}$. Denoting the announcement date, reported by SDC, as day 0, the estimation period ranges from day -220 to day -21 . The event window ranges from day 1 to day +1 .

\section{Methodology for the calculation of the long-run excess returns}

There is a large amount of literature on the calculation of long-run excess returns. In this literature a number of methods are proposed, most of which suffer from statistical

\footnotetext{
${ }^{10}$ A disadvantage of using single country indexes is that some European markets are fairly small and their indexes are largely dominated by a few large companies. An alternative would be to use a single European index for the whole sample. However, only a relatively limited number of observations in our sample are from small markets. Besides that, the use of a European index also has some disadvantages, since European capital markets are not fully integrated. Therefore the use of a single European index will introduce noise. For these reasons, we have chosen single country indexes.
} 
problems $^{11}$. We use one of the commonly accepted methodologies, i.e. the matching-firm approach of Barber and Lyon (1997) ${ }^{12}$. Within this matching firm approach we look in each country for a matching firm based on the size of a company and on its market-tobook ratio. More specifically, in the first month after the spin-off for which we have data in Compustat we divide all the companies in a certain market (country) into deciles based on the size of the company. Size is defined as the market value of equity. In the decile that includes the sample firm we look for the five companies that are closest to our sample firm in terms of the market-to-book ratio. The closest matching firm is designated as the first matching firm; the second closest matching firm is designated as the second matching firm and so on to the fifth matching firm. The stock return on the sample firm is then compared to the return on the matching firm. If the first matching firm disappears for whatever reason, we use the second matching firm from there on. If this firm also disappears, we continue with the third matching firm and so on. If the sample firm disappears, it is assumed that the proceeds are invested in its matching firm from that moment on. The application of this method only allows for the use of ordinary t-statistics for events that occur at random. Brav (2000) argues that a problem occurs if the events are not uncorrelated across firms as might be the case with spin-offs. Lyon et al. (1999) recognize this and they present a method to adjust t-statistics for overlapping samples. We use this methodology in our analysis. Following Lyon et al. (1999), we estimate the elements of the variance-covariance matrix $\Sigma$ for the overlapping long-run returns of firms $i$ and $j$ as

$$
\sigma_{i j}=\frac{1}{\tau-a} \sum_{t=s+a}^{s+\tau}\left(A R_{i t}-\overline{A R}_{i}\right)\left(A R_{j t}-\overline{A R}_{j}\right),
$$

where firm $i$ 's excess return is calculated from period $s$ to $s+\tau$, firm $j$ 's excess return is calculated from period $s+a$ to $s+a+\tau$, and $0 \leq a<\tau$. $A R_{i t}$ and $A R_{j t}$ are the monthly excess returns for firms $i$ and $j$, respectively, and $\overline{A R_{i}}$ and $\overline{A R_{j}}$ are their means calculated over

\footnotetext{
${ }^{11}$ See e.g. Barber and Lyon (1997), Fama (1998), Lyon et al. (1999), Brav (2000), Brav et al. (2000), and Loughran and Ritter (2000) for a discussion of the various methods.

12 This methodology was also used in recent studies by Desai and Jain (1999) on spin-offs, and by Eckbo et al. (2000) on seasoned equity offerings.
} 
the $\tau$ - $a$ overlap period. Lyon et al. (1999) show that this method reduces the misspecification due to the overlap of the long-run returns ${ }^{13}$.

The long-run returns on the combined firm reflect the total impact of a spin-off on the wealth of an investor holding the stock of the parent company prior to the reorganization. These returns are calculated as a weighted average of excess returns on the parent and subsidiary stock, where the relative market values of equity on the spin-off date (or on the first date after the spin-off that they are available) are used as weights.

\section{Results}

\subsection{Announcement date results}

The event study results for the whole sample are included in Table 2.

[Please put Table 2 here]

The results for all countries show a cumulative average abnormal return of $2.62 \%$ for the event window from day -1 to day +1 . This abnormal return is significant at the $1 \%$-level. The abnormal returns for smaller event windows, i.e. day 0 and day -1 to day 0 , are also significantly positive at the $1 \%$-level. These results are confirmed in the non-parametric sign test that tests for the number of positive observations. The results for Europe are in line with the American studies that were discussed in the introduction.

Separate results are presented for countries for which we have more than 10 observations. The cumulative average abnormal return for the United Kingdom is $2.54 \%$ for the event window from day -1 to day +1 . This return is also significant at the $1 \%$-level. Similar results are found for the windows from day -1 to day 0 and for day 0 . Our results for the event window day -1 to day 0 are in line with Murray (2000). However, he found an insignificant cumulative average abnormal return for the event window day -1 to day +1 , where we find a strongly significant cumulative average abnormal return.

\footnotetext{
${ }^{13}$ A similar method of correcting for cross-correlation of long-run excess returns was used by Mitchell and Stafford (2000). They assumed that correlations between overlapping returns are linearly decreasing in the overlapping period, and they based their estimates on the sub-sample of firms with complete overlap.
} 
For Italy we find a significantly positive cumulative average abnormal return of $7.97 \%$ for the event window from day -1 to day +1 . Sweden is the only exception with a cumulative average abnormal return of $0.82 \%$, which is not significantly different from zero $^{14}$. In the case of Germany we find a significantly positive cumulative average abnormal return of $2.56 \%$ for the day -1 to day +1 event window. This might indicate that German investors are not very afraid of being taxed in a later stage. The major shareholders of the company might have agreed that they would hold on to their shares for the 5-year period mentioned in the fiscal law.

Not all spin-offs that were announced in our sample period were completed as well. At the time of the completion of our analysis (April 2002), 108 spin-offs were completed. The other 48 spin-offs were withdrawn or, as in most cases, still pending. Since we are primarily interested in the question whether spin-offs create value, we also calculated mean cumulative abnormal returns for the sub-sample of completed spin-offs. The results are presented in Table 3.

\section{[Please put Table 3 here]}

In this table we see that the cumulative average abnormal return is $2.66 \%$ for the event window from day -1 to day +1 . This abnormal return is significant at the $1 \%$-level. It can be concluded that the returns for the whole sample and the returns for the completed sample are very close to each other ${ }^{15}$. Given our focus on the question whether spin-offs create value, we continue our analysis with the completed spin-offs ${ }^{16}$.

In Table 4 the event study results are presented for different sub-samples.

[Please put Table 4 here]

Unlike their method, the correction used by us does not require us to make an assumption about the correlation structure.

${ }^{14}$ The results for Sweden are partly driven by some announcements of Swedish banks that spun off big property divisions that they were forced to acquire during the loan crisis of the early 1990s. These announcements were generally associated with negative abnormal returns.

${ }^{15}$ Our results are different from those of Maxwell and Rao (2003). They study announcement results for completed and non-completed U.S. spin-offs. In their study they find significantly positive abnormal returns for both samples. However, the announcement returns for the sample of completed spin-offs are significantly higher than for the sample of non-completed spin-offs.

${ }^{16}$ A disadvantage of this approach is that we introduce a look-ahead bias by assuming that investors know which spin-offs will actually be carried out and which ones will not. However, a comparison of Tables 3 and 4 shows that the results are very much alike. Detailed results for the whole sample are available on request from the authors. 
In Panel A the event study results are compared for companies that increase industrial focus and for firms that do not increase industrial focus. In total 73 companies increase their industrial focus by carrying out a spin-off. The mean abnormal return for these companies is $3.57 \%$. The mean abnormal return for the 35 companies in the nonindustrial-focus sub-sample is only $0.76 \%$. The difference between the two samples is $2.80 \%$. This difference is significant on the $5 \%$-level. The difference in the medians of the two samples is $1.82 \%$, which is significant on the $10 \%$-level. This is similar to the earlier reported results for the United States by Daley et al. (1997), Krishnaswami and Subramaniam (1999), and Desai and Jain (1999). They find that the abnormal returns are larger for the focus-increasing spin-offs than for the non-focus increasing spin-offs.

In panel B we compare abnormal returns between companies with a high information asymmetry and companies with low information asymmetry. The high information asymmetry sub-sample is associated with a mean cumulative average abnormal return of $1.44 \%$ and the low information asymmetry sub-sample exhibits a cumulative average abnormal return of $3.45 \%$. We hypothesized the inverse relationship. However, both the mean and the median difference are not significantly different from zero.

In panel $\mathrm{C}$ we compare the high and low shareholder protection sub-samples. They show mean cumulative average abnormal returns of $2.17 \%$ and $3.30 \%$ respectively. The mean and medians are not significantly different from zero.

Finally, in Panel D the results are compared for companies that spun off a foreign division and for companies that spun off a domestic division. The mean cumulative average abnormal return for the companies that spun off a foreign division is $2.81 \%$. The mean cumulative average return for the companies that spun off a domestic division is $2.65 \%$. The difference is a positive $0.17 \%$. However, this difference is not statistically significant.

In Table 5 the regression results are presented for the cumulative average abnormal returns of the subsequently completed spin-offs over the three-day interval.

[Please put Table 5 here]

Although the total number of completed spin-offs is 108 , the maximum number of observations in Table 5 is 84 . This is caused by the inclusion of a control variable that measures the size of the spun-off subsidiary relative to the size of the parent company. 
This variable is referred to as relative size. Unfortunately this variable is only available for a limited number of companies. The reason for this is that this variable is only available if Datastream reports both the market value of equity of the parent and the market value of equity of the subsidiary. In a number of cases the subsidiary is not traded on a major stock exchange and, therefore, we do not have reliable data on the market value of equity of the subsidiary. In a few cases, the subsidiary is traded, but its market value is not reported in Datastream. These two factors explain the reduction of the sample size from 108 to 84 companies. The first regression in Table 5 shows that industrial focus has a positive and significant coefficient. This confirms the earlier reported results from Table 4. In regression (2) we include both industrial focus and the normalized standard deviation of forecasts. The last mentioned coefficient has a very small t-statistic. This is in line with the results in Table 4. Therefore, we conclude that, contrary to Krishnaswami and Subramaniam (1999), we do not find any relationship between the announcement returns and the level of asymmetric information. The inclusion of the normalized standard deviation of forecasts leads to a disappearance of the significance of the industrial focus variable. In regression (3) we include a measure for shareholder protection ("the shareholder rights"). This variable does not show the expected positive sign, but it shows a negative sign instead. However, this coefficient is not significant. This can be explained by the fact that spin-offs are considered to be value creating in countries with different levels of shareholder protection. In this regression, the sign for industrial focus becomes significant again. In regression (4) we include both industrial and geographical focus. The geographical focus variable is not significant. This is probably caused by the fact that the positive effects on the increase of geographical focus are canceled out by the negative effects. Like in the previous regression, the variable on industrial focus is significant. Finally, in regression (5) we include all four variables. In this regression the variable for industrial focus is no longer significant. This leaves us with some mixed evidence on this variable. We conclude that industrial focus does play a role, but its importance is limited. The coefficient for size is significantly different from zero in all regressions. This confirms earlier results from e.g. Hite and Owers (1983), and Miles and Rosenfeld (1983) that large spin-offs are associated with higher abnormal returns. 


\subsection{Long-run performance}

In Table 6 the annualized long-run excess returns of the parent companies, the subsidiaries and the pro-forma combined firms in the period after the spin-off are included.

[Please put Table 6 here]

There is a discussion in the literature on the use of equal-weighted returns versus valueweighted returns. Loughran and Ritter (2000) argue that equal-weighted returns are more relevant from the point of view of an investor who wants to predict the abnormal returns associated with a random event. Fama (1998), on the other hand, argues that valueweighted returns should be studied, because they more accurately capture the total wealth effects that are experienced by investors. The implications for market efficiency can be completely different. This point is very well illustrated by Brav et al. (2000). They present a scenario in which a sample contains 1,000 firms, 999 of which have a \$ 1 million market capitalization (the "small firms") and one firm that has a \$1,001 million market capitalization (the "large firm"). If it is assumed that the small firms have all underperformed by an equal percentage of $50 \%$, while the large firm has overperformed by $50 \%$, it can be seen that an equal-weighted measure will indicate a severe mispricing $(-50 \%)$, while a value weighting will lead to the conclusion that the sample performance is virtually zero. From our perspective we prefer the analysis of equal-weighted returns. The reason for this is that we want to test whether a random spin-off will be associated with long-run superior performance. Therefore, our focus will be on the equal-weighted returns. However, in order to also capture the value effects for the market as a whole, we furthermore present value-weighted returns.

In Table 6 the excess returns are calculated as the difference between the company returns and the returns on a matching firm. This matching procedure is described in section 3.3. With regard to Table 6 it has to be pointed out that the number of observations goes down with the study horizon because there are shorter time series available for the more recent announcements. This is caused by the fact that our last 
announcement stems from September 2000. First the equal-weighted returns will be discussed.

In Panel A, the results for the parent companies are presented. The mean annualized returns are positive for the periods of 6 months and 2 years after the spin-off and are negative for the periods of 1 year and 3 years after the spin-off. However, all returns are insignificant. Our results differ from previous results that were published for the United States. For example, Cusatis et al. (1993), and Desai and Jain (1999) find that parents of spin-offs perform significantly better than similar firms in the 3-year period after the spin-off.

In Panel B we present the results for the subsidiaries. This sample only shows insignificant mean excess returns. This result is different from earlier results for the United States. Desai and Jain (1999) find significantly positive excess returns for their sample of subsidiaries.

A spin-off involves a pro-rata distribution of shares of the subsidiary. This enables us to create a pro-forma combined firm in the period following the spin-off. Following Desai and Jain (1999), we create this "firm" by weighting the return of the parent and that of the subsidiary by the market value of equity at the spin-off date ${ }^{17}$. This gives us the return an investor would have earned if he had held on to the shares of both the parent and the subsidiary after the spin-off. In panel $\mathrm{C}$ of Table 6 , we see that the pro-forma combined firms are associated with non-significantly negative mean excess returns in the 6-month and the 1-year periods after the spin-offs. The mean excess returns in the 2 year and 3year periods after the event are positive, but also insignificant.

A close look at the equal-weighted returns in Table 6 reveals that there is definitely no significant long-run effect for spin-offs. Although the number of observations in panel A is fairly high (between 68 and 106), all t-statistics are very small (between -0.12 and 1.50). This result is also found for the subsidiaries (panel B) and for the pro-forma combined firms (panel C).

Table 6 also includes value-weighted returns. Panel A shows insignificant mean excess returns for the 6 months and the 1-year periods after the spin-off. The period of 2 years after the spin-off shows a significantly positive excess return. However, it turns into a

\footnotetext{
${ }^{17}$ Desai and Jain (1999) use the market value of equity at the end of the month of the spin-off.
} 
non-significant mean excess return in the 3-year post spin-off period. We study whether this decline is created by a reversal of a company for which both data on the 2-year and the 3-year periods are available, or whether it is caused by a company for which no 3year data are available. We find that the decline is mainly caused by the Swiss company Novartis. In the 2-year period this company, that has a weight of $21.31 \%$ in the sample, shows an excess return of $45.90 \%$. This excess return drops to $1.79 \%$ over the 3 -year period after the spin-off. The subsidiaries in panel B show significantly negative mean excess returns in the 6 month and 2 year periods after the spin-off. However, the 1 year and 3 year periods show non-significant returns. The pro-forma combined firms in panel $\mathrm{C}$ mostly have insignificant returns. The significantly positive return for the 2-year period in panel $\mathrm{C}$ is caused by the same outlier as in panel A.

Brav et al. (2000), and Loughran and Ritter (2000) argue that researchers should be careful with drawing conclusions for market efficiency from studies on long-run excess returns. This warning is based on the fact that e.g. equal- and value-weighted returns can lead to different conclusions. If we review our results it can be concluded that the valueweighted returns, and even more so the equal-weighted returns, indicate that the European markets are efficient. This gives some support for the idea of Fama (1998) that the long-run effects following U.S. spin-offs are rather a result of chance than of causality. However, given the warnings of Brav et al. (2000), and Loughran and Ritter (2000) it should be noticed that more research on different capital markets is necessary before a definite conclusion can be drawn.

In Table 7 the relation between the long-run excess returns of the parent firms and their underlying variables is studied.

\section{[Please insert Table 7 here]}

We focus on the 1-year and the 2-year excess returns. The reason for this is that we want to study a relatively long period after the completion of the spin-off. Therefore, we leave out the 6-month excess returns. As we only have a limited number of observations for the 3-year period, we also leave out these results. In regression (1) we present the results for the 1-year excess returns; regression (2) shows the results for the 2-year horizon. The industrial focus variable has very low t-statistics in both regressions. The results for this variable are different from the result of Desai and Jain (1999), who find that US firms 
that increase their industrial focus with a spin-off exhibit higher long run excess returns than firms that do not increase their industrial focus. The coefficient for the relative size of spin-off is insignificant. The geographical focus variable is significantly negative in both regressions. We study whether this result is caused by negative earnings surprises for these companies. Earnings forecast data are available for five of the six companies in Table 7 that spin off a foreign division. For three of them negative earnings surprises in the first post-spin-off year are followed by negative abnormal returns. For another firm, a small positive earnings surprise of less than five percent is followed by negative long-run performance. In only one case we find that a positive earnings surprise is followed by a positive abnormal return. Overall, these companies experience an average earnings surprise of -242.47 percent of the expected earnings in the first post spin-off year, with a median of -28.99 percent. Therefore, we conclude that the high negative coefficient for geographical focus improvement is explained by negative earnings surprises.

The pre-spin-off level of information asymmetry is not significant in both regressions. Therefore, we do not find any support for the hypothesis that firms with higher information asymmetry before the spin-off display better long-run performance. We also test the model of Habib et al. (1997) by measuring the impact of the changes in the information asymmetry on the long-run performance of spin-off parents. The change in the normalized standard deviation of forecasts exhibits the expected negative sign in both regressions. However, this sign is only significant in the first regression. Therefore, we conclude that there is some, albeit weak, evidence for the model of Habib et al. (1997). Overall, it can be concluded that there is no real evidence for the model of Habib et al. (1997). The coefficient for the shareholder rights shows a negative sign in both regressions. Moreover, in one of the regressions this coefficient is statistically significant. This is remarkable since it means that a higher level of shareholder protection is associated with lower long-run excess returns. It is unlikely that this finding can be explained by the more or less shareholder-friendly treatment of spin-offs in different countries, since we saw in Tables 3, 4, and 5 that the announcement returns were very similar in countries with different shareholder protection. This result can possibly be explained by the fact that firms that undertake spin-offs also continue to maintain their shareholder-oriented policy in the long run. Our methodology controls for the financial 
characteristics of the matching firms in the sense that we look for firms with similar size and book-to-market value. However, it is possible that in countries with less shareholder protection, the "average firm" that is used as a match is more likely to undertake actions that benefit other stakeholders rather than the shareholders, while the firms that perform spin-offs are more focussed on shareholder value maximization. It is possible that this creates a long-run difference in the stock price performance between the sample and the matching firms. On the other hand, in countries with a good shareholder protection, such as the United Kingdom, other firms are more forced to act in the interests of shareholders than in a country like Belgium. This may explain the significantly negative sign for the shareholder rights variable in two out of six regressions in Table 7.

From a market efficiency point of view it is interesting to study whether the announcement period returns and the long-run excess returns are related. This analysis is included in Table 8.

[Please insert Table 8 here]

We find that for the six months and 1-year post spin-off periods, the day 0 abnormal returns are positively related to the long-run excess returns. This would indicate that the market underreacts to the spin-off announcement. However, the coefficient is insignificantly negative for the 2-year post spin-off period and insignificantly negative for the 3-year period. The finding of a possible underreaction is also not confirmed for the three-day announcement period abnormal returns since the coefficients for all four regressions are insignificant. Furthermore, it can be remarked that the explanatory power of all regressions is extremely small. The adjusted $R^{2}$ varies between -0.02 and 0.03 . Therefore, it can be concluded that there is not much evidence for underreaction at the announcement date.

\section{Summary and conclusions.}

We study the wealth effects and the efficiency of the European capital market for the case of corporate spin-offs. Announcements of spin-offs may be associated with positive abnormal returns if the spin-off is associated with a wealth increase for the shareholders. Such a wealth increase can be accomplished if the spin-off leads to an increase in 
industrial or geographical focus or if the spin-off leads to a decrease of the information asymmetry between the management of the firm and its shareholders. The efficient market hypothesis implies that there is no long-run effect. Possible wealth effects will be incorporated in the stock price at the moment the spin-off is announced.

We study announcement effects and long-run performance for a sample of 156 European spin-offs announced from January 1987 to September 2000. We find that the announcement of a subsequently completed spin-off is associated with a positive abnormal return of 2.66 percent over a three-day window. We find some evidence that the abnormal returns are related to an increase in the industrial focus. There does not seem to be a relationship between the abnormal returns and the level of information asymmetry at the time of the spin-off. In line with the efficient market hypothesis we do not find any significant long-run excess return in the period after the spin-off. If the return on the parents, subsidiaries and the pro-forma combined firms is compared to the return on a matching portfolio, we find that the excess returns are both economically and statistically insignificant. 


\section{References:}

- Barber, B.M., and Lyon, J.D.: "Detecting long-run abnormal stock returns: the empirical power and specification of test statistics", Journal of Financial Economics, 1997, page 341-372.

- Bodnar, G.M., Tang, C., and Weintrop, J.: "Both sides of corporate diversification: The value impacts of geographic and industrial diversification", Working paper, Johns Hopkins University, April 2000.

- Brav, A.: "Inference in long-horizon event studies: a Bayesian approach with application to initial public offerings", The Journal of Finance, 2000, page 19792016.

- Brav, A., Geczy, C., and Gompers, P.A.: "Is the abnormal return following equity issuances anomalous?", Journal of Financial Economics, 2000, page 209-249.

- Copeland, T.E., Lemgruber, E.F., and Mayers, D.: "Corporate spinoffs: multiple announcement and ex-date abnormal performance", In: "Modern Finance and Industrial Economics: Papers in honor of J. Fred Weston”, T.E. Copeland (ed.), Basil Blackwell Inc., 1987, page 114-137.

- Cusatis, P.J., Miles, J.A., and Woolridge, J.R.: "Restructuring through spinoffs: the stock market evidence", Journal of Financial Economics, 1993, page 293-311.

- Daley, L., Mehrotra, V., and Sivakumar, R.: "Corporate focus and value creation: evidence from spinoffs", Journal of Financial Economics, 1997, page 257-281.

- Denis, D.J., Denis, D.K., and Yost, K.: "Global diversification, industrial diversification, and firm value", The Journal of Finance, 2002, page 1951-1980.

口 Desai, H., and Jain, P.C.: "Firm performance and focus: long-run stock market performance following spinoffs", Journal of Financial Economics, 1999, page 75101.

- Dittmar, A.: "Capital structure in corporate spin-offs", Journal of Business (forthcoming), 2003.

- Eckbo, B.E., Masulis, R.W., and Norli, O.: "Seasoned public offerings: resolution of the "new issues puzzle", Journal of Financial Economics, 2000, page 251-291.

- Fama, E.F.: "Market efficiency, long-term returns, and behavioral finance", Journal of Financial Economics, 1998, page 283-306.

- Gibbs, P.: "Quarterly focus: European spin-off market", Morgan Guaranty Trust Company, Mergers \& Acquisitions Research, London, April 23, 1999.

- Habib, M.A., Johnsen, B.D., and Naik, N.Y.: "Spinoffs and information", Journal of Financial Intermediation, 1997, page 153-176.

a Hite, G.L., and Owers, J.E.: "Security price reactions around corporate spin-off announcements", Journal of Financial Economics, 1983, page 409-436.

- Janssens de Vroom, H., and Van Frederikslust, R.: "Shareholder wealth effects of corporate spinoffs", Working Paper, Erasmus University, Rotterdam, June 2000.

- Johnson, S.A., Klein, D.P., and Thibodeaux, V.L.: "The effects of spin-offs on corporate investment and performance", The Journal of Financial Research, 1996, page 293-307.

- Krishnaswami, S., and Subramaniam, V.: "Information asymmetry, valuation, and the corporate spin-off decision”, Journal of Financial Economics, 1999, page 73-112. 
- La Porta, R., Lopez-de-Silanes, F., Shleifer, A., and Vishny, R.: "Law and finance", Journal of Political Economy, 1998, page 1113-1155.

- La Porta, R., Lopez-de-Silanes, F., Shleifer, A., and Vishny, R.: "Investor protection and corporate governance", Journal of Financial Economics, 2000, page 3-28.

- Loughran, T., and Ritter, J.R.: "Uniformly least powerful tests of market efficiency", Journal of Financial Economics, 2000, page 361-389.

- Lyon, J.D., Barber, B.M., and Tsai, C.L.: "Improved methods for tests of long-run abnormal stock returns", The Journal of Finance, 1999, page 165-201.

- Maxwell, W.F., and Rao, R.P.: "Do spin-offs expropriate wealth from bondholders", The Journal of Finance (forthcoming), 2003.

- McConnell, J.J., Ozbilgin, M., and Wahal, S.: "Spin-offs, ex ante", Journal of Business, 2001, page 245-280.

- Mikkelson, W.H., and Partch, M.M.: "Valuation effects of security offerings and the issuance process", Journal of Financial Economics, 1986, page 31-60.

- Miles, J.A., and Rosenfeld, J.D.: "The effect of voluntary spin-off announcements on shareholder wealth", The Journal of Finance, 1983, page 1597-1606.

- Mitchell, M.L., and Stafford, E.: "Managerial decisions and long-term stock price performance", Journal of Business, 2000, page 287-329.

- Moerland, P.W.: "Alternative disciplinary mechanisms in different corporate systems", Journal of Economic Behavior and Organization, 1995, page 17-34.

- Mulherin, J.H., and Boone, A.L.: "Comparing acquisitions and divestitures", Journal of Corporate Finance, 2000, page 117-139.

- Murray, L.: "An assessment of the wealth effects of spin-offs on the London Stock Exchange", Working Paper, University College Dublin, June 2000.

- Parrino, R.: "Spin-offs and wealth transfers: the Marriott case", Journal of Financial Economics, 1997, page 241-274.

a Poetgens, F.P.G., and Jakobsen, M.: "Netherlands: Tax-neutral division of companies", European Taxation, March 1999, page 81-88.

- Raedler, A.J.: "General report on the conference on national and international tax consequences of demergers", International Fiscal Association, Toronto, 1994.

- Rosenfeld, J.D.: "Additional evidence on the relation between divestiture announcements and shareholder wealth", The Journal of Finance, 1984, page 14371448.

- Schipper, K., and Smith, A.: "Effects of recontracting on shareholder wealth: the case of voluntary spin-offs", Journal of Financial Economics, 1983, page 437-467.

- Slovin, M.B., Sushka, M.E., and Ferraro, S.R.: "A comparison of the information conveyed by equity carve-outs, spin-offs and asset sell-offs", Journal of Financial Economics, 1995, page 89-104.

- Van Olffen, M., Buijn, F.K., and Simonis, P.H.M.: "Splitsing van ondernemingen (transl. Split-ups of companies)", Boom Juridische Uitgevers, Deventer (the Netherlands), 1998.

- Zaman, D.F.M.M.: "Splitsing: juridisch en fiscaal (transl. Split-up: legal and fiscal)", Kluwer Juridische Uitgevers, Deventer (the Netherlands), 1998. 
Table 1: Observations by announcement year

Distribution of European companies that announced a spin-off in the period from January 1987 to September 2000 by announcement year and country of the parent company. The spin-off announcements are identified from the Securities Data Company (SDC) Mergers and Acquisitions Database. Spin-offs are eliminated for the following reasons: (1) double records of companies that announce the spin-off of two or more subsidiaries on the same dates, (2) spin-offs by multiple parents and (3) spin-offs for which no Datastream price data are available and/or for which the announcement was contaminated with other important news on the company. Countries are denoted as follows: UK for United Kingdom, GER for Germany, FRA for France, ITA for Italy, SWE for Sweden, NOR for Norway, DEN for Denmark, FIN for Finland, NL for the Netherlands, B for Belgium, CH for Switzerland, SP for Spain, AUS for Austria, IRE for Ireland and GRE for Greece.

\begin{tabular}{|c|c|c|c|c|c|c|c|c|c|c|c|c|c|c|c|c|}
\hline Year & UK & GER & FRA & ITA & SWE & NOR & DEN & FIN & NL & B & $\mathrm{CH}$ & SP & AUS & IRE & GRE & Total \\
\hline 1987 & 2 & 1 & & & & & & & & & & & & & & 3 \\
\hline 1988 & 2 & & 2 & & & 1 & & & & & & & & & & 5 \\
\hline 1989 & 7 & & & & & 1 & & & 1 & & & & & & & 9 \\
\hline 1990 & 6 & & 1 & & & & 1 & & & & & & & & & 8 \\
\hline 1991 & 6 & 1 & & & 1 & 5 & & & 2 & & & & & & & 15 \\
\hline 1992 & 2 & 1 & & & 2 & 1 & & 1 & & & & & & & & 7 \\
\hline 1993 & 4 & & & & 1 & 1 & & & & & & & & 2 & & 8 \\
\hline 1994 & 3 & & & 1 & 1 & & & 1 & & & & & 1 & & & 7 \\
\hline 1995 & 11 & 1 & & 1 & & 1 & & & 1 & & & 1 & & & & 16 \\
\hline 1996 & 10 & & 3 & 1 & 9 & 1 & & & & & 2 & & & & & 26 \\
\hline 1997 & 11 & 1 & & 1 & 3 & & & & & & 1 & & & & & 17 \\
\hline 1998 & 13 & 5 & & 1 & 7 & 2 & & & 3 & & & & & & & 31 \\
\hline 1999 & 10 & 4 & & 5 & 4 & 3 & 2 & 1 & & 1 & 3 & & & 1 & & 34 \\
\hline 2000 & 15 & 4 & 1 & 4 & 2 & 2 & & 3 & & 1 & 3 & 3 & 2 & & 4 & 44 \\
\hline $\begin{array}{l}\text { Total number of } \\
\text { observations }\end{array}$ & 102 & 18 & 7 & 14 & 30 & 18 & 3 & 6 & 7 & 2 & 9 & 4 & 3 & 3 & 4 & 230 \\
\hline -/- multiple announcements & 8 & 1 & 2 & & & 1 & 1 & 2 & & & & & & & 1 & 16 \\
\hline $\begin{array}{l}\text {-/- no stock prices in } \\
\text { Datastream or } \\
\text { contaminating information }\end{array}$ & 17 & 4 & & 3 & 6 & 7 & 1 & 2 & 3 & & 3 & 2 & 1 & 1 & 1 & 51 \\
\hline -/- multiple parents & 7 & & & & & & & & & & & & & & & 7 \\
\hline Total sample & 70 & 13 & 5 & 11 & 24 & 10 & 1 & 2 & 4 & 2 & 6 & 2 & 2 & 2 & 2 & 156 \\
\hline Completed & 51 & 4 & 2 & 8 & 22 & 8 & 1 & 2 & 2 & 2 & 3 & 0 & 1 & 2 & 0 & 108 \\
\hline
\end{tabular}


Table 2: Abnormal returns on the announcement date

Cumulative average abnormal returns for the whole sample of 156 spin-off announcements by European companies from January 1987 to September 2000. The spin-off announcements are identified from the Securities Data Company (SDC) Mergers and Acquisitions Database. Abnormal returns are based on the market model, estimated over a 200 day-period for each company (from day -220 to day -21). The significance of the medians is tested by means of the Wilcoxon signed rank test. The sign test is used to test the significance of the percentage of firms with positive abnormal returns. The null-hypothesis for the sign test is that the proportion of positive cumulative average abnormal returns is equal to 50 percent. Asterisks indicate significance at the $10 \%\left(^{*}\right), 5 \%\left(\left(^{* *}\right)\right.$ and $1 \%$ $\left(^{* * *}\right)$ level.

\begin{tabular}{|c|c|c|c|c|}
\hline \multirow[b]{2}{*}{ Interval } & \multicolumn{4}{|c|}{ Cumulative average abnormal returns } \\
\hline & Mean \% & z-statistic & Median & Percentage positive \\
\hline \multicolumn{5}{|c|}{ All Europe $(\mathbf{N}=156)$} \\
\hline-10 to -1 & 0.77 & $3.50^{* * *}$ & 0.49 & 53.21 \\
\hline-1 to 0 & 1.74 & $8.99^{* * *}$ & $0.61^{* * *}$ & $58.97^{* *}$ \\
\hline 0 & 1.19 & $8.30^{* * *}$ & $0.27^{* * *}$ & $62.82^{* * *}$ \\
\hline-1 to +1 & 2.62 & $10.23^{* * *}$ & $0.89^{* * *}$ & $62.82^{* * *}$ \\
\hline+1 to +10 & -0.33 & -0.27 & -0.03 & 49.36 \\
\hline \multicolumn{5}{|l|}{ Including: } \\
\hline \multicolumn{5}{|c|}{$\mathrm{UK}(\mathbf{N}=\mathbf{7 0})$} \\
\hline-10 to -1 & 1.18 & $2.79^{* * *}$ & 0.61 & $60.00^{*}$ \\
\hline-1 to 0 & 2.19 & $7.72^{* * *}$ & $0.95^{* * *}$ & $61.43^{*}$ \\
\hline 0 & 1.88 & $8.91^{* * *}$ & $0.62^{* * *}$ & $67.14^{* * *}$ \\
\hline-1 to +1 & 2.54 & $7.39^{* * *}$ & $0.50^{* * *}$ & $60.00^{*}$ \\
\hline+1 to +10 & -1.68 & -0.87 & -0.27 & 47.14 \\
\hline \multicolumn{5}{|c|}{ Sweden $(N=24)$} \\
\hline-10 to -1 & 1.12 & $1.96^{* *}$ & 1.64 & 54.17 \\
\hline-1 to 0 & 0.66 & 1.17 & -0.00 & 50.00 \\
\hline $\mathbf{0}$ & 0.57 & 0.88 & 0.04 & 58.33 \\
\hline-1 to +1 & 0.82 & 0.87 & 0.11 & 58.33 \\
\hline+1 to +10 & 2.24 & 0.22 & -0.38 & 41.67 \\
\hline
\end{tabular}


Table 2: Continued.

\begin{tabular}{|c|c|c|c|c|}
\hline \multirow[b]{2}{*}{ Interval } & \multicolumn{4}{|c|}{ Cumulative average abnormal returns } \\
\hline & Mean \% & z-statistic & Median & Percentage positive \\
\hline \multicolumn{5}{|c|}{ Germany $(N=13)$} \\
\hline-10 to -1 & 4.42 & $1.94^{*}$ & $2.26^{*}$ & 61.54 \\
\hline-1 to 0 & 2.49 & $2.89^{* * *}$ & 0.24 & 53.85 \\
\hline 0 & 0.69 & 1.28 & 0.12 & 53.85 \\
\hline-1 to +1 & 2.56 & $2.08^{* *}$ & 0.04 & 53.85 \\
\hline+1 to +10 & 1.14 & 0.68 & 2.03 & 69.23 \\
\hline \multicolumn{5}{|c|}{ Italy $(\mathrm{N}=11)$} \\
\hline-10 to -1 & -1.11 & -0.38 & -2.17 & 36.36 \\
\hline-1 to 0 & 3.62 & $5.75^{* * *}$ & $2.43^{*}$ & 72.73 \\
\hline 0 & 1.51 & $3.84^{* * *}$ & 1.03 & 72.73 \\
\hline-1 to +1 & 7.97 & $8.28^{* * *}$ & $4.16^{* *}$ & $81.82^{*}$ \\
\hline+1 to +10 & 2.89 & 1.62 & 0.64 & 54.55 \\
\hline
\end{tabular}


Table 3: Abnormal returns on the announcement date: Completed spin-offs

Cumulative average abnormal returns for the sub-sample of 108 announcements of spin-offs by European companies from January 1987 to September 2000 that were subsequently completed. The spin-off announcements are identified from the Securities Data Company (SDC) Mergers and Acquisitions Database. Abnormal returns are based on the market model, estimated over a 200 dayperiod for each company (from day -220 to day -21). The significance of the medians is tested by means of the Wilcoxon signed rank test. The sign test is used to test the significance of the percentage of firms with positive abnormal returns. The null-hypothesis for the sign test is that the proportion of positive cumulative average abnormal returns is equal to 50 percent. Asterisks indicate significance at the $10 \%\left({ }^{*}\right), 5 \%\left(^{* *}\right)$ and $1 \%\left(^{* * *}\right)$ level.

\begin{tabular}{|c|c|c|c|c|}
\hline \multirow[b]{2}{*}{ Interval } & \multicolumn{4}{|c|}{ Cumulative average abnormal returns } \\
\hline & Mean \% & z-statistic & Median & Percentage positive \\
\hline \multicolumn{5}{|c|}{ All Europe $(\mathbf{N}=108)$} \\
\hline-10 to -1 & 0.62 & $2.57^{* *}$ & 0.58 & 54.63 \\
\hline-1 to 0 & 1.75 & $7.20^{* * *}$ & $0.69^{* * *}$ & $60.19^{* *}$ \\
\hline $\mathbf{0}$ & 1.25 & $6.98^{* * *}$ & $0.17^{* *}$ & $60.19^{* *}$ \\
\hline-1 to +1 & 2.66 & $8.06^{* * *}$ & $0.90^{* * *}$ & $61.11^{* *}$ \\
\hline+1 to +10 & -0.35 & -0.80 & -0.28 & 46.30 \\
\hline \multicolumn{5}{|l|}{ Including: } \\
\hline \multicolumn{5}{|c|}{ UK $(\mathbf{N}=51)$} \\
\hline-10 to -1 & 1.39 & $2.19^{* *}$ & 0.87 & $64.71^{* *}$ \\
\hline-1 to 0 & 2.33 & $6.80^{* * *}$ & $1.04^{* * *}$ & 60.78 \\
\hline 0 & 1.93 & $7.83^{* * *}$ & $0.69^{* * *}$ & $66.67^{* *}$ \\
\hline-1 to +1 & 2.41 & $5.38^{* * *}$ & $0.39^{* *}$ & 60.78 \\
\hline+1 to +10 & -2.07 & $-1.96^{*}$ & -0.60 & 41.18 \\
\hline \multicolumn{5}{|c|}{ Sweden $(\mathrm{N}=22)$} \\
\hline-10 to -1 & 0.81 & $1.92^{*}$ & 1.64 & 54.55 \\
\hline-1 to 0 & 0.71 & 1.19 & -0.00 & 50.00 \\
\hline $\mathbf{0}$ & 0.57 & 0.81 & 0.03 & 54.55 \\
\hline-1 to +1 & 0.87 & 0.88 & 0.06 & 54.55 \\
\hline+1 to +10 & -0.52 & -0.97 & -0.38 & 40.91 \\
\hline
\end{tabular}


Table 3: Continued.

\begin{tabular}{|c|c|c|c|c|}
\hline \multirow[b]{2}{*}{ Interval } & \multicolumn{4}{|c|}{ Cumulative average abnormal returns } \\
\hline & Mean \% & z-statistic & Median & Percentage positive \\
\hline \multicolumn{5}{|c|}{ Germany $(N=4)$} \\
\hline-10 to -1 & 4.78 & 0.72 & 4.77 & 50.00 \\
\hline-1 to 0 & 2.04 & 1.09 & 1.75 & 75.00 \\
\hline $\mathbf{0}$ & -0.67 & -0.33 & -1.23 & 25.00 \\
\hline-1 to +1 & 3.42 & 1.42 & 2.82 & 50.00 \\
\hline+1 to +10 & 0.44 & -0.09 & 2.15 & 50.00 \\
\hline \multicolumn{5}{|c|}{ Italy $(\mathbf{N}=\mathbf{8})$} \\
\hline-10 to -1 & -2.67 & -1.28 & -2.43 & 25.00 \\
\hline-1 to 0 & 2.20 & $3.31^{* * *}$ & 1.29 & 75.00 \\
\hline $\mathbf{0}$ & 1.61 & $3.58^{* * *}$ & 0.69 & 75.00 \\
\hline-1 to +1 & 7.87 & $6.83^{* * *}$ & $3.18^{* *}$ & 75.00 \\
\hline+1 to +10 & 7.14 & $3.37^{* * *}$ & $4.40^{* *}$ & 75.00 \\
\hline
\end{tabular}


Table 4: Announcement period abnormal returns of the completed spin-offs by sub-sample

Three-day cumulative average abnormal returns for sub-samples of 108 announcements of spin-offs by European companies from January 1987 to September 2000 that were subsequently completed. The spin-off announcements are identified from the Securities Data Company (SDC) Mergers and Acquisitions Database. Abnormal returns are based on the market model, estimated over a 200 day-period for each company (from day -220 to day -21). Industrial-focus increasing spin-offs are defined as spin-offs of subsidiaries that have a two-digit SIC-code that is different from the parent company. High (Low) level of information asymmetry is defined as being above (below) the medium asymmetry value. High level of shareholders' protection includes countries with anti-director rights index equal to 4 or 5 . Low level of shareholders' protection includes countries with anti-director rights index equal to $0,1,2$ and 3. Geographical focus-increasing spin-offs are defined as spin-offs of subsidiaries from a different country than the parent firm. The significance of the means is tested using a t-statistic. The significance of the medians is tested by means of the Wilcoxon signed rank test. The difference in means is tested using a t-statistic. The difference in medians is tested using the Mann-Whitney statistic. Asterisks indicate significance at the $10 \%\left(^{*}\right), 5 \%\left(^{* *}\right)$ and $1 \%\left(^{* * *}\right)$ level.

\section{Panel A: Cumulative average abnormal returns $(-1,+1)$ for sub-samples based on industrial focus}

\begin{tabular}{|c|c|c|c|c|c|c|c|c|}
\hline & \multicolumn{3}{|c|}{ Increase industrial focus } & \multicolumn{3}{|c|}{ Do not increase industrial focus } & \multicolumn{2}{|c|}{ Difference } \\
\hline & Mean & Median & $\mathbf{N}$ & Mean & Median & $\mathbf{N}$ & Mean & Median \\
\hline CAR & 3.57 & 1.74 & 73 & 0.76 & 0.26 & 35 & 2.80 & 1.48 \\
\hline Test statistics & $4.00^{* * *}$ & $4.04^{* * *}$ & & 1.36 & 1.07 & & $2.08^{* *}$ & $1.82^{*}$ \\
\hline
\end{tabular}

Panel B: Cumulative average abnormal returns $(-1,+1)$ for sub-samples based on information asymmetry (Normalized Standard Deviation of Forecast)

\begin{tabular}{|c|c|c|c|c|c|c|c|c|}
\hline & \multicolumn{3}{|c|}{ High information asymmetry } & \multicolumn{3}{|c|}{ Low information asymmetry } & \multicolumn{2}{|c|}{ Difference } \\
\hline & Mean & Median & $\mathbf{N}$ & Mean & Median & $\mathbf{N}$ & Mean & Median \\
\hline CAR & 1.44 & 0.23 & 46 & 3.45 & 1.44 & 45 & -2.01 & -1.21 \\
\hline Test statistics & $2.01^{*}$ & $1.72^{*}$ & & $2.78^{* * *}$ & $2.80^{* * *}$ & & 1.41 & 1.14 \\
\hline
\end{tabular}


Table 4: Continued.

Panel C: Cumulative average abnormal returns $(-1,+1)$ for sub-samples based on the level of shareholders' protection

\begin{tabular}{|c|c|c|c|c|c|c|c|c|}
\hline & \multicolumn{3}{|c|}{ High shareholders' protection } & \multicolumn{3}{|c|}{ Low shareholders' protection } & \multicolumn{2}{|c|}{ Difference } \\
\hline & Mean & Median & $\mathbf{N}$ & Mean & Median & $\mathbf{N}$ & Mean & Median \\
\hline CAR & 2.17 & 0.39 & 61 & 3.30 & 1.95 & 47 & -1.13 & -1.56 \\
\hline Test statistics & $2.84^{* * *}$ & $2.32^{* *}$ & & $3.02^{* * *}$ & $3.37^{* * *}$ & & 0.87 & 1.07 \\
\hline
\end{tabular}

Panel D: Cumulative average abnormal returns $(-1,+1)$ for sub-samples based on geographical focus

\begin{tabular}{|c|c|c|c|c|c|c|c|c|}
\hline & \multicolumn{3}{|c|}{ Increase geographical focus } & \multicolumn{3}{|c|}{ Do not increase geographical focus } & \multicolumn{2}{|c|}{ Difference } \\
\hline & Mean & Median & $\mathbf{N}$ & Mean & Median & $\mathbf{N}$ & Mean & Median \\
\hline CAR & 2.81 & 1.53 & 8 & 2.65 & 0.89 & 100 & 0.17 & 0.64 \\
\hline Test statistics & 1.70 & 1.33 & & $3.89^{* * *}$ & $3.77^{* * *}$ & & 0.07 & 0.36 \\
\hline
\end{tabular}


Table 5: Regression of abnormal returns for completed spin-offs.

Regression coefficients for the three-day cumulative average abnormal returns for the completed announcements of 84 spin-offs by European companies from January 1987 to September 2000. Only includes the results for only those completed spin-offs for which the relative size of the spin-off is known. The spin-off announcements are identified from the Securities Data Company (SDC) Mergers and Acquisitions Database. Industrial focus is a dummy variable equal to 1 if the first two digits of the primary SIC code of a subsidiary to be spun-off are different from the first two digits of the primary SIC code of the parent company, and 0 otherwise. The normalized standard deviation of forecasts is measured as the standard deviation of the analyst earnings forecasts in the last months of the fiscal year preceding the spin-off announcement, divided by the stock price. The "shareholder rights" index is a summary measure of shareholder protection. This index ranges from zero to seven. The source of these data is La Porta et al. (1998). Geographical focus is a dummy variable equal to 1 in the case of a spin-off of a foreign subsidiary, and equal to 0 if the spin-off is domestic. The relative size is equal to the ratio of the market value of the spun-off subsidiary equity to the sum of the market values of the equity of the parent and the subsidiary on the day of the spin-off. Asterisks indicate significance at the $10 \%\left(^{*}\right), 5 \%\left(^{* *}\right)$ and $1 \%\left(^{* * *}\right)$ level, based on White heteroscedasticity-adjusted standard errors. t-statistics are in parentheses.

\begin{tabular}{|c|c|c|c|c|c|}
\hline Variable & (1) & (2) & (3) & (4) & (5) \\
\hline \multirow{2}{*}{ Intercept } & -2.075 & -1.917 & 1.138 & -2.122 & 2.298 \\
\hline & $(-1.378)$ & $(-0.996)$ & $(0.563)$ & $(-1.418)$ & $(1.125)$ \\
\hline \multirow[t]{2}{*}{ Industrial focus } & $2.666^{* *}$ & 1.865 & $2.213^{*}$ & $2.669^{* *}$ & 1.092 \\
\hline & (2.337) & $(1.452)$ & $(1.831)$ & (2.336) & $(0.809)$ \\
\hline \multirow[t]{2}{*}{ Relative size } & $10.162^{* *}$ & $11.805^{*}$ & $11.124^{* *}$ & $10.180^{* *}$ & $13.081^{* *}$ \\
\hline & (2.147) & $(1.910)$ & $(2.156)$ & $(2.152)$ & $(2.132)$ \\
\hline Normalized standard & & -14.512 & & & -23.493 \\
\hline deviation of forecasts & & $(-0.453)$ & & & $(-0.773)$ \\
\hline \multirow[t]{2}{*}{ Shareholder rights } & & & -0.844 & & -1.114 \\
\hline & & & $(-1.199)$ & & $(-1.556)$ \\
\hline \multirow[t]{2}{*}{ Geographical focus } & & & & 0.549 & 1.699 \\
\hline & & & & $(0.299)$ & $(0.621)$ \\
\hline Number of observations & 84 & 72 & 84 & 84 & 72 \\
\hline $\mathrm{R}^{2}$ & 0.160 & 0.161 & 0.188 & 0.160 & 0.211 \\
\hline Adjusted $\mathrm{R}^{2}$ & 0.139 & 0.124 & 0.157 & 0.129 & 0.151 \\
\hline
\end{tabular}


Table 6: Long-run returns in excess of the matching firm return

Annualized returns defined as company stock price return minus matching firm return for spin-offs by European companies from January 1987 to September 2000. The spin-offs are identified from the Securities Data Company (SDC) Mergers and Acquisitions Database. The pro-forma combined firm is created by weighing the return of the parent and that of the subsidiary by the market value of equity at the spin-off date. The equal-weighted returns are calculated as the average excess returns for the whole sample. The valueweighted excess returns are calculated as the average excess returns weighted by the market values at the spin-off dates. The significance of the means is tested using a t-statistic, corrected for the cross-correlation of long-run returns. $t_{\mathrm{sp}}$ is the spin-off ex-date. $\mathrm{t}_{\mathrm{sp}}+6(12,24,36)$ is the period from the spin-off date to $6(12,24,36)$ months after the spin-off date. Asterisks indicate significance at the $10 \%\left(^{*}\right), 5 \%\left(^{* *}\right)$ and $1 \%\left(^{* * *}\right)$ level.

\begin{tabular}{|c|c|c|c|c|c|c|}
\hline & \multirow{2}{*}{$\begin{array}{c}\text { Number of } \\
\text { observations }\end{array}$} & \multicolumn{2}{|c|}{ Equal-weighted } & \multicolumn{2}{|c|}{ Value-weighted } & \multirow{2}{*}{$\begin{array}{c}\text { Percentage } \\
\text { positive }\end{array}$} \\
\hline & & Mean & t-statistic & Mean & t-statistic & \\
\hline & \multicolumn{6}{|c|}{ Panel A: All parent firms } \\
\hline$t_{s p}$ to $t_{s p}+6$ & 106 & 3.88 & 0.27 & 1.32 & 0.18 & 48.11 \\
\hline$t_{s p}$ to $t_{s p}+12$ & 105 & -0.65 & -0.12 & 4.43 & 1.44 & 49.52 \\
\hline$t_{s p}$ to $t_{s p}+24$ & 86 & 6.49 & 1.50 & $14.28^{* * *}$ & 5.31 & 59.30 \\
\hline$t_{s p}$ to $t_{s p}+36$ & 68 & -0.41 & -0.10 & -3.96 & -1.37 & 48.53 \\
\hline \multicolumn{7}{|c|}{ Panel B: All subsidiaries } \\
\hline$t_{s p}$ to $t_{s p}+6$ & 70 & 11.96 & 0.66 & $-24.45^{* *}$ & -2.17 & 50.00 \\
\hline$t_{s p}$ to $t_{s p}+12$ & 70 & 12.58 & 0.83 & -15.75 & -1.17 & 52.86 \\
\hline$t_{s p}$ to $t_{s p}+24$ & 60 & 13.72 & 1.03 & $-22.04^{*}$ & -1.69 & 65.00 \\
\hline$t_{s p}$ to $t_{s p}+36$ & 53 & 15.15 & 0.97 & 4.62 & 0.30 & 67.92 \\
\hline \multicolumn{7}{|c|}{ Panel C: All pro-forma combined firms } \\
\hline$t_{s p}$ to $t_{s p}+6$ & 61 & -2.23 & -0.25 & 0.80 & 0.12 & 44.26 \\
\hline$t_{s p}$ to $t_{s p}+12$ & 61 & -2.33 & -0.45 & -0.89 & -0.18 & 49.18 \\
\hline$t_{s p}$ to $t_{s p}+24$ & 51 & 4.24 & 1.00 & $8.49^{*}$ & 1.79 & 60.78 \\
\hline$t_{s p}$ to $t_{s p}+36$ & 45 & 2.01 & 0.43 & 1.61 & 0.48 & 53.33 \\
\hline
\end{tabular}




\section{Table 7: Regression of long-run excess return: Parent firms}

Regression coefficients for the one- and two-year returns in excess of the matching portfolio return for the European companies that performed a spin-off. The spin-off dates are identified from the Securities Data Company (SDC) Mergers and Acquisitions Database. Industrial focus is a dummy variable equal to 1 if the first two digits of the primary SIC code of a subsidiary to be spun-off are different from the first two digits of the primary SIC code of the parent company, and 0 otherwise. Geographical focus is a dummy variable equal to 1 in the case of a spin-off of a foreign subsidiary, and equal to 0 if the spinoff is domestic. The normalized standard deviation of forecasts is measured as the standard deviation of the analyst earnings forecasts in the last months of the fiscal year preceding the spin-off announcement, divided by the stock price. Changes in the normalized standard deviation of forecasts are measured from the end of fiscal year preceding the spin-off announcement to the end of the fiscal year in which the spin-off is completed. The "shareholder rights" index is a summary measure of shareholder protection. This index ranges from zero to seven. The source of these data is La Porta et al. (1998). The relative size is equal to the ratio of the market value of the spun-off subsidiary equity to the sum of the market values of the equity of the parent and the subsidiary on the day of the spin-off. Asterisks indicate significance at the $10 \%\left({ }^{*}\right), 5 \%\left({ }^{* *}\right)$ and $1 \%\left({ }^{* * *}\right)$ level, based on White heteroscedasticityadjusted standard errors. t-statistics are in parentheses.

\begin{tabular}{lrr}
\hline Variable & $\begin{array}{c}\text { One-year } \\
\text { excess return }\end{array}$ & $\begin{array}{c}\text { Two-year } \\
\text { excess return }\end{array}$ \\
\hline Intercept & 6.978 & $30.413^{*}$ \\
Industrial focus & $(0.355)$ & $(1.893)$ \\
& -2.141 & -0.811 \\
Geographical focus & $(-0.189)$ & $(-0.066)$ \\
& $-40.971^{* *}$ & $-24.237^{*}$ \\
Relative size & $(-2.167)$ & $(-1.942)$ \\
& -0.582 & 26.809 \\
Normalized standard deviation & $(-0.027)$ & $(1.375)$ \\
of forecasts & -241.083 & -620.783 \\
Change in normalized standard & $(-0.531)$ & $(-1.545)$ \\
deviation of forecasts & $-850.904^{*}$ & -57.401 \\
Shareholder rights & $(-1.746)$ & $(-0.131)$ \\
& -1.953 & $-7.090^{* *}$ \\
Number of observations & $(-0.513)$ & $(-2.254)$ \\
$\mathrm{R}^{2}$ & 62 & 52 \\
Adjusted $\mathrm{R}^{2}$ & 0.205 & 0.215 \\
\hline
\end{tabular}


Table 8: Regression of long-run excess return on the abnormal returns on announcement date Regression coefficients for the six-month to three-year returns on a pro-forma combined firm for the European companies that performed a spin-off. The spin-off dates are identified from the Securities Data Company (SDC) Mergers and Acquisitions Database. Day 0 and day -1 to day +1 abnormal returns are based on the market model, estimated over a 200 day-period for each company (from day 220 to day -21). The six-month to three-years annualized excess returns are defined as company stock price return minus matching firm return. The pro-forma combined firm is created by weighing the return of the parent and that of the subsidiary by the market value of equity at the spin-off date.

Asterisks indicate significance at the $10 \%\left(^{*}\right), 5 \%\left(\left(^{* *}\right)\right.$ and $1 \%\left(^{* * *}\right)$ level, based on White heteroscedasticity-adjusted standard errors. t-statistics are in parentheses.

\begin{tabular}{|c|c|c|c|c|c|c|c|c|}
\hline \multirow[b]{2}{*}{ Constant } & \multicolumn{2}{|c|}{ Six months } & \multicolumn{2}{|c|}{ One year } & \multicolumn{2}{|c|}{ Two years } & \multicolumn{2}{|c|}{ Three years } \\
\hline & $\begin{array}{l}-6.628 \\
(-0.703)\end{array}$ & $\begin{array}{l}-3.902 \\
(-0.391)\end{array}$ & $\begin{array}{l}-7.959 \\
(-1.441)\end{array}$ & $\begin{array}{l}-3.318 \\
(-0.581)\end{array}$ & $\begin{array}{l}4.715 \\
(0.822)\end{array}$ & $\begin{array}{l}3.707 \\
(0.691)\end{array}$ & $\begin{array}{l}1.314 \\
(0.293)\end{array}$ & $\begin{array}{l}0.227 \\
(0.055)\end{array}$ \\
\hline $\begin{array}{l}\text { Day } 0 \\
\text { abnormal } \\
\text { return }\end{array}$ & $\begin{array}{l}4.434^{* *} \\
(2.013)\end{array}$ & & $\begin{array}{l}3.287^{*} \\
(1.715)\end{array}$ & & $\begin{array}{l}-0.307 \\
(-0.170)\end{array}$ & & $\begin{array}{l}1.248 \\
(0.846)\end{array}$ & \\
\hline $\begin{array}{l}\text { Day }-1 \text { to day } \\
+1 \text { abnormal } \\
\text { return }\end{array}$ & & $\begin{array}{l}0.041 \\
(0.036)\end{array}$ & & $\begin{array}{l}-0.839 \\
(-1.536)\end{array}$ & & $\begin{array}{l}0.598 \\
(0.350)\end{array}$ & & $\begin{array}{l}1.401 \\
(1.227)\end{array}$ \\
\hline $\begin{array}{l}\text { Number of } \\
\text { observations }\end{array}$ & 54 & 54 & 54 & 54 & 45 & 45 & 39 & 39 \\
\hline Adjusted $\mathrm{R}^{2}$ & 0.01 & -0.02 & 0.03 & 0.01 & -0.02 & -0.02 & -0.01 & 0.03 \\
\hline
\end{tabular}




\section{Appendix: The regulatory and fiscal environment for European spin-offs}

Spin-offs are legally possible in all European countries. For members of the European union the 6th EC-directive on corporation law is important ${ }^{18}$. This directive, that defines the legal terms for splitups, stems from December 17, 1982. Member states were advised to incorporate it in their laws by January $1,1986^{19}$. However, in some countries it took longer to incorporate this directive in the national law. For example, in Belgium corporate law did not cover split-ups until June 29, 1993 (Zaman, 1998). This does not mean that split-ups were illegal. They were permitted and they were in general legally arranged using the framework that was set in the fiscal law. In Europe, the legal frameworks for spin-offs are generally based on the laws for split-ups. However, in some cases it took some time before a special framework for spin-offs was set up. For example, until February 1998, Dutch companies that wanted to spin-off one or more divisions had to go through a large range of complicated procedures. This ended on February 1, 1998 with the adoption of a law in which matters were significantly simplified (see Van Olffen et al. 1998).

In principle, spin-offs may cause an income tax problem, because they can be seen as a distribution of income or capital and can be taxed accordingly. On July 23, 1990 the European Union adopted the so-called "Merger Directive". According to this directive, the capital gains taxation on a spinoff is deferred. In other words, the tax authorities consider a spin-off as the re-arrangement of investments that the investor already owns, and as a result, levy no taxes. This directive applies to intra-community spin-offs. The ultimate intention for this directive is its application in all countries within the European Union ${ }^{20}$. According to Gibbs (1999), tax deferral does not cause major problems in most European countries. Like in the United States, it is important that the spin-offs are carried out for business reasons. In some countries, spin-offs are associated with potential fiscal problems. This is the case for the Netherlands (until June 1998), Germany and France. Before June 1998, spin-offs in the Netherlands were seen as a distribution of income or capital and they were taxed accordingly. Under the pressure of some large Dutch companies spin-offs were no longer taxed from June 1998 onwards. Instead, the fiscal claims were passed on to the future ${ }^{21}$. This opened the way for one of the largest European spin-offs in which the Dutch company KPN spun

\footnotetext{
${ }^{18}$ The following countries are member states of the European union. As of 1951: Belgium, France, Germany, Italy, Luxembourg and the Netherlands. As of 1973: Denmark, Ireland and the United Kingdom. As of 1981: Greece. As of 1986: Spain and Portugal. As of 1995: Austria, Finland and Sweden.

${ }^{19}$ Note that countries are not obliged to incorporate the directive.

${ }^{20}$ See Raedler (1994).

${ }^{21}$ See Poetgens and Jakobsen (1999), and Van Olffen et al. (1998).
} 
off its postal division TNT Post Groep ${ }^{22}$. Besides that, two other relatively large spin-offs could be realized. In Germany spin-offs can be arranged in a tax-neutral way. However, if more than $20 \%$ of the shareholders transfer their shares within 5 years after the spin-off, the spin-off will still be taxed (Zaman, 1998). In France a problem occurs in the sense that it is not possible for the company to ask for approval from the tax authorities before the transaction is carried out. This uncertainty is probably the cause of the low number of spin-offs that were announced in France. In the period from January 1987 to September 2000 a mere total of 7 spin-offs were announced in France.

\footnotetext{
${ }^{22}$ The market value of KPN and TNT Post Groep after the spin-off were respectively 17.9 billion US \$ and 11.6 billion US \$, making it one of the largest spin-offs in Europe.
} 